\title{
AN EMPIRICAL STUDY ON OCCUPATIONAL STRESS OF TEACHERS WORKING IN HIGHER EDUCATIONAL INSTITUTIONS IN MYSURU
}

\author{
SREELALITHA. K. $\mathbf{G}^{1} \&$ DR. S. SHANKARAPPA ${ }^{2}$ \\ ${ }^{I}$ Research Scholar, JSS Research Foundation, SJCE Campus, Manasagangotri, \\ Mysuru, Karnataka, India \\ ${ }^{2}$ Associate Professor \& Research Guide, Department of Commerce \& Management,
}

JSS College, Mysuru, Karnataka, India

Stress is common in every aspect of human walk. It is a universal phenomenon and now-a-days no organization can claim to be stress-free. Every job is challenging and more demanding. Each job requires a high standard of performance, high quality and getting aspirations and expectation fulfilled. Every employee is forced to have a stressful and hectic lifestyle. The topic was selected with the overall purpose of understanding the phenomenon of stress among faculty members and to find out how they struggle with stress in higher educational institutions. The main objective of the study is to identify the causes of occupational stress among teachers working in higher educational institutions. The other objectives of the study are to know about the relationship between experience and level of stress, to determine the influence of gender on level of stress, to determine the impact of working environment on the level of stress and to identify the level of stress faced by teachers in the study area. The data were collected from primary and secondary sources. A questionnaire was used to collect primary data from a sample of 100 faculty members working in higher educational institutions in Mysuru. The secondary data were collected through research articles, books, magazines, journals, and web sites. Percentage analysis, Average, Range, Standard Deviation, Correlation, and ANOVA were used as tools for the study. Bar diagram and Pie charts were also used to represent statistical data. The result of the analysis indicates that the teachers working in higher educational institutions work under pressure and suffer from occupational stress because of poor working environment.
\end{abstract}

KEYWORDS: Higher Educational Institutions, Teachers, Environment Stress \& Causes

Received: Apr 13, 2019; Accepted: May 03, 2019; Published: Jun 01, 2019; Paper Id.: IJESRJUN20198

\section{INTRODUCTION}

Stress is basically the impact of one object on another. There are three terms which are used to denote this phenomenon; Stress, strain, and pressure. However, there are thin differences between these terms. Stress is a term basically used in physical sciences which means the pressure of one object on another. In other words, the term stress is the body's general response to environmental situations ${ }^{1}$. "Job or occupational stress is a condition that arises from the interaction of people and their jobs and characterized by changes within people that force them to deviate from their normal functioning'. Thus, stress is an adaptive response to an external factor that results in physical, psychological and behavioural deviations in an individual.

In India the role of higher education is vital and it is encouraging to increase human development. Higher education in India has experienced widespread expansion since independence. In almost all the sectors India has 
produced various resource persons. Employees stress is becoming a worldwide concern. It is no longer taken as a problem which is faced only by the employees or the workers working in the Industrial sector. It is currently considered as an issue that needs to be tackled by the employees working in Educational Institutions also. The tremendous growth and excellence in higher educational institutions can be achieved only when the teachers work with stress-free mind. Therefore, it is essential to know and find the factors which lead to stress among teachers in higher educational institutions. Most commonly, the teachers working in higher educational institutions suffer from occupational stress when there is an improper work environment, organization problems, deprived relations with colleagues, lack of recognition, changing role and increased expectations by the higher authority, increased responsibilities and other major factors which contribute to the stress factor.

\section{REVIEW OF LITERATURE}

BREWER AND LANDERS (2003) in their research "Relationship between Job Stress and Job Satisfaction among Industrial and Technical Teacher Educators", took a random sample of 133 industrial and technical teacher educators. The research revealed a strong correlation analysis. They found an inverse relationship between the constructs, with stressors related to lack of organizational support being more strongly associated with job satisfaction than stressors related to the job itself were.

ZHANG.JIANWEI (2010) in the study entitled Organizational climate and its effects on organizational Variables: An empirical study, has investigated the characteristics of organizational climate and its effects on organizational variables such as turnover intentions, job satisfaction, work efficiency, job stress and organisational commitment. The researcher finds out that organizational climate not only effects on human resource effectiveness but also effect on organization effectiveness.

DHANABHAKYAM \& ANITHA (2011) in a Study On Stress Management of Working Women In Coimbatore District, have emphasized on causes and control of stress among women employees, the result of the study that young age working women are highly stressful than the middle and aged women. This shows that age and stress are related. The young aged working women can avoid or reduce stress by sharing their problem with their supervisors, spouse, family member, and doctors.

PARILLA S. ERIC (2012) Level of Stress Experienced by NWU Employees: towards developing stress management, has determined the level of stress experienced by NWU (NORTHWESTERN UNIVERSITY) employees. The researcher finds out that the middle-level employees experienced the highest degree of stress and the level of stress compared to the other job position. The result that personal characteristics (age, gender, income number of family members) have not correlated to job stress while job position has correlated with job stress. Productivity and stress have negatively correlated.

VIJAYADURAI \& VENKATESH (2012), in a Study on Stress Management among Women College Teachers in Tamil-Nadu, India, emphasized that Workplace stress occurs when there is an imbalance in the demands and perceived pressures of the work environment and an individual ability to cope. 


\section{OBJECTIVES OF THE STUDY}

The objectives of the study are

- To determine the impact of the working environment on the level of stress.

- To identify the relationship between experience and level of stress

- To determine the influence of gender on stress

- To measure the level of stress faced by teachers in the study area

- To identify the causes of occupational stress

\section{HYPOTHESES}

This study assumes the following hypotheses;

H1: There exists a significant relationship between experience and level of stress

H2: Gender influences the level of stress

H3: There exists a significant relationship between Poor working environment and stress.

H4: There is a correlation between job role and level of stress

H5: Job insecurity leads to more stress

\section{METHODOLOGY}

The present study is based on both Primary data and Secondary data. The questionnaire was used to collect primary data from a sample of 100 faculty members working in higher educational institutions in Mysuru. The secondary data were collected through Research Articles, Books, Magazines, Journals, and Websites.

Simple bar diagrams are used to represent the statistical data and the analysis is done with the help of Percentage Analysis, Average, Range, Standard Deviation, Correlation and ANOVA (SPSS).

\section{FINDINGS AND DISCUSSIONS}

\section{Percentage Analysis}

Age is a key factor in identifying the level of stress. For the purpose of the study, age was classified into different categories like 20 to 30 years, 30-40 years, 40-50 years and above 50 years. The distribution of the sample respondents according to their age is shown in the following table.

Table 1: Percentage of Respondents According to Age

\begin{tabular}{|c|c|c|c|}
\hline Sl.No. & Age in Years & No. of Respondents & Percentage \\
\hline 1 & $20-30$ & 38 & 38.0 \\
\hline 2 & $30-40$ & 24 & 24.0 \\
\hline 3 & $40-50$ & 22 & 22.0 \\
\hline 4 & Above 50 & 16 & 16.0 \\
\hline \multicolumn{2}{|c|}{ Total } & $\mathbf{1 0 0}$ & $\mathbf{1 0 0}$ \\
\hline
\end{tabular}




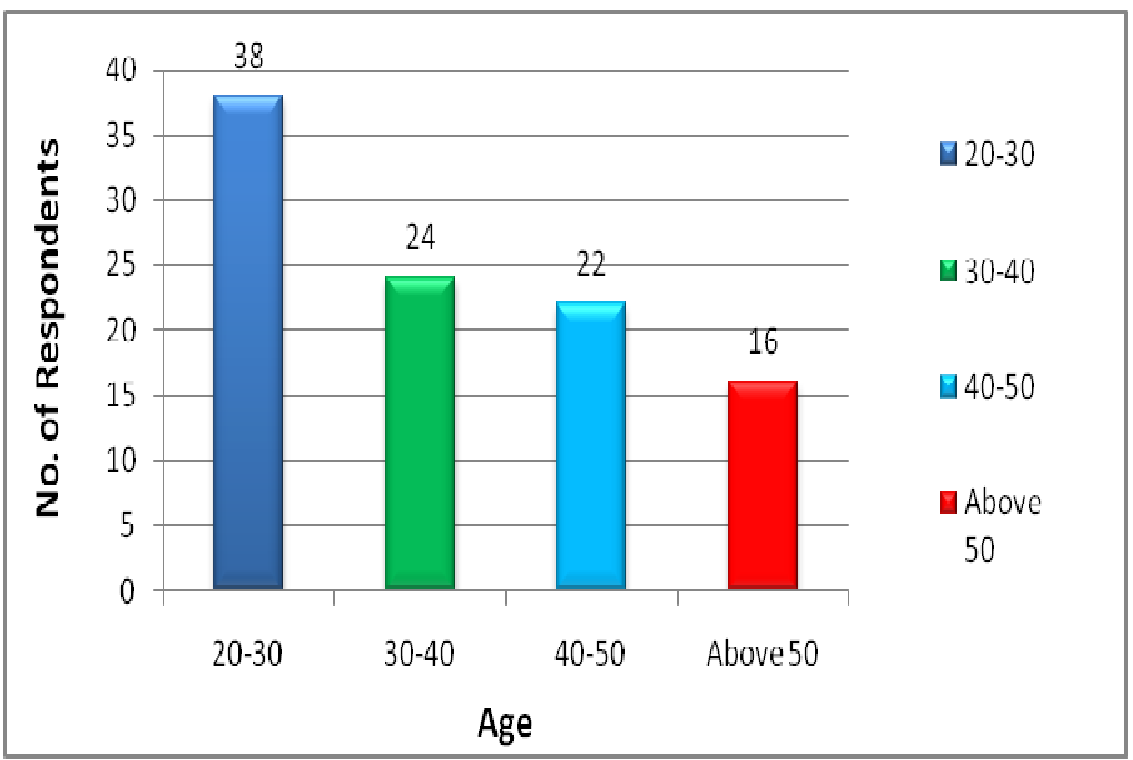

Chart 1: Percentage of Respondents According to Age

The above chart indicates, among the selected sample, 38 (38\%) respondents are in the age group of 20-30 years, $24(24 \%)$ respondents are in the age group of 30-40 years, $22(22 \%)$ respondents are in the age group of 40-50 years and $16(16 \%)$ respondents are in the age group of above 50 years.

Table 2: Percentage of Respondents According to Age and Gender Age * Gender Cross Tabulation

\begin{tabular}{|c|c|c|c|c|c|c|}
\hline \multirow{2}{*}{ Age } & \multicolumn{4}{|c|}{ Gender } & \multirow{2}{*}{ Total } & \multirow{2}{*}{ Percentage } \\
\hline & Male & Percentage & Female & Percentage & & \\
\hline $20-30$ & 14 & 38.89 & 24 & 37.5 & 38 & 38.0 \\
\hline $30-40$ & 6 & 16.67 & 18 & 28.12 & 24 & 24.0 \\
\hline $40-50$ & 8 & 22.22 & 14 & 21.88 & 22 & 22.0 \\
\hline Above 50 & 8 & 22.22 & 8 & 12.5 & 16 & 16.0 \\
\hline Total & 36 & 100 & 64 & 100 & 100 & 100 \\
\hline
\end{tabular}

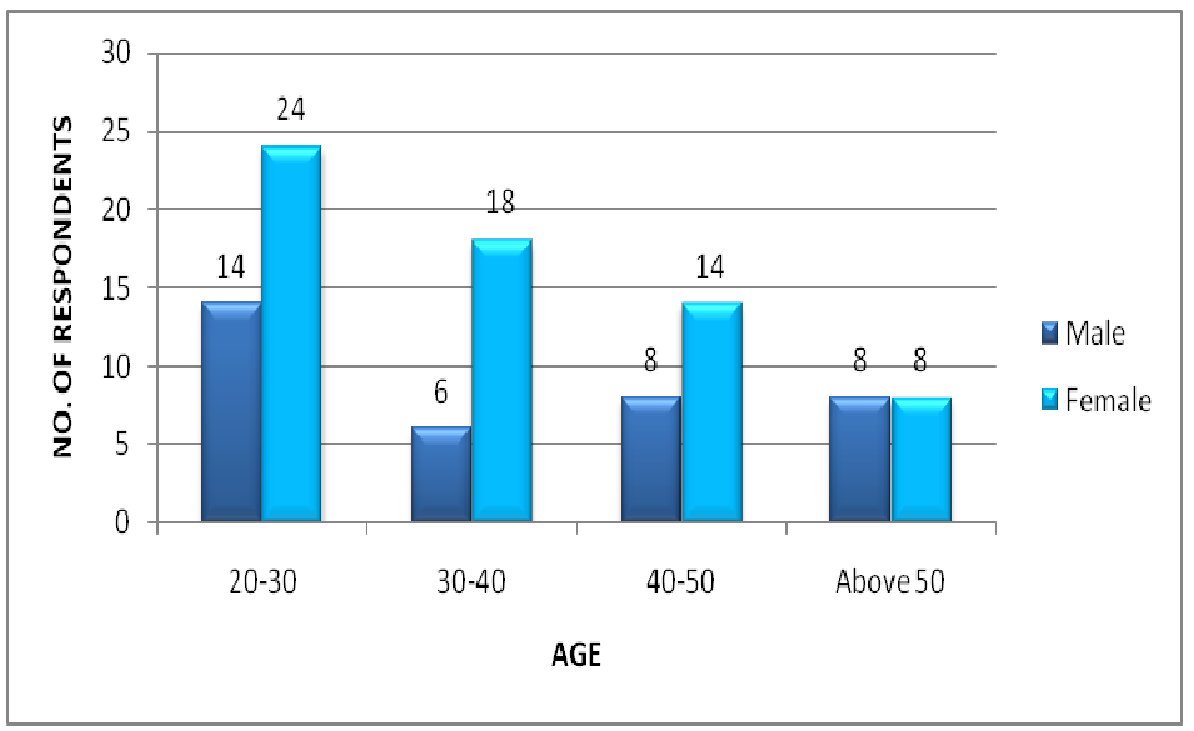

Chart 2: Percentage of Respondents According to Age and Gender 
The above chart indicates, among the selected sample of male and female, 14 male (38.89\%) \& 24 female (37.5) respondents are in the age group of 20-30 years, 6 male $(16.67 \%) \& 18$ female $(28.12 \%)$ respondents are in the age group of $30-40$ years, 8 male $(22.22 \%) \& 14$ female $(21.88 \%)$ respondents are in the age group of $40-50$ years and , 8 male $(22.22 \%) \& 8$ female $(12.5 \%)$ respondents are in the age group of above 50 years.

Table 3: Opinion of Respondents

\begin{tabular}{|c|c|c|c|c|c|c|c|c|c|c|c|c|c|c|c|c|c|c|c|c|c|}
\hline \multirow{3}{*}{ SOURCE } & \multicolumn{20}{|c|}{ EXPERIENCE } & \multirow{3}{*}{ Total } \\
\hline & \multicolumn{5}{|c|}{1 to 5 Years } & \multicolumn{5}{|c|}{5 to 10 Years } & \multicolumn{5}{|c|}{10 to 15 Years } & \multicolumn{5}{|c|}{ Above 15 Years } & \\
\hline & SA & $\mathrm{A}$ & $\mathrm{N}$ & D & SD & SA & $\mathrm{A}$ & $\mathrm{N}$ & $\mathrm{D}$ & SD & SA & $\mathrm{A}$ & $\mathrm{N}$ & D & SD & SA & $\mathrm{A}$ & $\mathrm{N}$ & D & SD & \\
\hline Role conflictleads to stress & 5 & 5 & 14 & 11 & - & 7 & 9 & 4 & 9 & 2 & 3 & 6 & 1 & 2 & 1 & 1 & 9 & 3 & 7 & 1 & 100 \\
\hline Lack of support results in stress & 5 & 10 & 7 & 8 & 5 & 7 & 8 & 6 & 7 & 3 & 7 & 3 & & 2 & 1 & 3 & 6 & 5 & 6 & 1 & 100 \\
\hline Poor relationships at work place leads to stress & 7 & 10 & 10 & 5 & 5 & 7 & 5 & 3 & 11 & 5 & 3 & 7 & 2 & 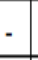 & 1 & 4 & 10 & . & 4 & 2 & 100 \\
\hline Job insecurity leads to stress & 4 & 11 & 7 & 10 & 3 & 11 & 2 & 12 & 3 & 3 & 5 & 3 & 3 & 2 & - & 4 & 1 & 2 & 7 & 7 & 100 \\
\hline $\begin{array}{l}\text { Poor pay prospects results in work related } \\
\text { stress }\end{array}$ & 7 & 7 & 6 & 9 & 6 & 4 & 14 & 3 & 5 & 5 & 6 & 3 & & & 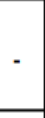 & 3 & 8 & 4 & 5 & 1 & 100 \\
\hline Excess of control leads to stress & 2 & 12 & 13 & 7 & - & 2 & 14 & 4 & 4 & 7 & 7 & 1 & 2 & 2 & & 3 & 8 & & 3 & 3 & 100 \\
\hline
\end{tabular}

SA-Strongly Agree, A- Agree, N- Neutral, D -Disagree \& SD - Strongly Disagree

The data collected was coded with least indicates 1 and maximum indicates 5 on the Likert 5-point scale (Likert-5 point scale coded as 1, 2, 3, $4 \& 5$ ). The above table provides information regarding the opinion of respondents to the questionnaire.

\section{ANOVA ANALYSIS}

Experience and Level of Stress

Table 4: Experience and Level of Stress

\begin{tabular}{|c|c|c|c|c|c|c|}
\hline \multirow{2}{*}{$\begin{array}{c}\text { Experience } \\
\text { in Years }\end{array}$} & \multirow{2}{*}{$\begin{array}{c}\text { No. of } \\
\text { Respondents }\end{array}$} & \multirow{2}{*}{ Percentage } & \multirow{2}{*}{ Average } & \multicolumn{2}{|c|}{ Range } & Standard \\
\cline { 5 - 7 } & & & Minimum & Maximum & Deviation \\
\hline $1-5$ & 35 & 35.0 & 19.69 & 12 & 29 & 5.572 \\
\hline $5-10$ & 31 & 31.0 & 21.81 & 12 & 36 & 6.204 \\
\hline $10-15$ & 13 & 13,0 & 19.15 & 15 & 32 & 5.097 \\
\hline Above 15 & 21 & 21.0 & 17.90 & 9 & 29 & 5.476 \\
\hline Total & $\mathbf{1 0 0}$ & $\mathbf{1 0 0}$ & & & & \\
\hline
\end{tabular}

The above table indicates, the respondents who come under 5-10 years of experience level, experience high stress with an average of 21.81 and ranged from

12 and 36, followed by the respondents in the experience level of 10-15years with an average of 19.15 and ranged between 15 and 32. The respondents in the experience level of Above 15yearswith an average of 17.90, ranged between 9 and 29. On the other hand, the respondents of 1-5 years of experience level resulted in an average of 19.69and ranged between 12 and 29. Thus it can be concluded as the respondents of 5-10 years of experience level, experience a high level of stress.

In order to find the relationship between the experience of the respondents and their level of stress, an ANOVA test was used and the result of the test is shown in the following table. 
Table 5: Showing the Analysis of the Relationship between Experience and Stress ANOVA

\begin{tabular}{|c|c|c|c|c|l|}
\hline \multicolumn{1}{|c|}{ Total } & $\begin{array}{c}\text { Sum of } \\
\text { Squares }\end{array}$ & $\begin{array}{c}\text { Degrees of } \\
\text { Freedom }\end{array}$ & Mean Square & F value & $\begin{array}{c}\text { Level of } \\
\text { Significance }\end{array}$ \\
\hline Between Groups & 258.679 & 3 & 86.226 & 2.493 & Significant @ $5 \%$ \\
Within Groups & 830.000 & 24 & 34.583 & & \\
\hline Total & $\mathbf{1 0 8 8 . 6 7 9}$ & $\mathbf{2 7}$ & & & level \\
\hline
\end{tabular}

It is observed from the above table that, the calculated $\mathrm{F}$ valueis greater than the table value and the result is significant at $5 \%$ level. Hence the alternative hypothesis "There exists a significant relationship between experience and level of stress" holds good. From this analysis, it is identified that there is a significant relationship between experience and level of stress.

Result - H1

There exists a significant relationship between experience and the level of stress is proved.

Table 6: Showing Gender and Level of Stress: Age * Gender Cross Tabulation

\begin{tabular}{|l|c|c|c|}
\hline \multirow{2}{*}{ Age } & \multicolumn{2}{|c|}{ Gender } & \multirow{2}{*}{ Total } \\
\cline { 2 - 3 } & Male & Female & \\
\hline $20-30$ & 14 & 21 & 35 \\
\hline $30-40$ & 13 & 18 & 31 \\
\hline $40-50$ & 3 & 10 & 13 \\
\hline Above 50 & 8 & 13 & 21 \\
\hline Total & $\mathbf{3 8}$ & $\mathbf{5 2}$ & $\mathbf{1 0 0}$ \\
\hline
\end{tabular}

Table 7: Showing the Analysis of the Relationship Between Gender and Stress ANOVA

\begin{tabular}{|c|c|c|c|c|c|}
\hline Total & Sum of Squares & Df & Mean Square & F value & LOS \\
\hline Between Groups & 156.729 & 1 & 156.729 & 1.917 & \multirow{2}{*}{ Significant @ 5\% level } \\
\hline Within Groups & 7631.756 & 93 & 82.062 & & \\
\hline Total & $\mathbf{7 7 8 8 . 4 8 4}$ & $\mathbf{9 4}$ & & & \\
\hline
\end{tabular}

According to the above analysis, the $\mathrm{F}$ value 1.917 is greater than the table value and the result is significant at $5 \%$ level. Hence there is a significant relationship between gender and level of stress.

\section{Result - H2}

There exists a significant relationship between gender and level of stress is proved

Table 8: Showing the Correlation between Job Role and Stress CORRELATIONS

\begin{tabular}{|l|l|c|c|}
\hline \multicolumn{2}{|l|}{} & Age & $\begin{array}{c}\text { I have to Play } \\
\text { More than One } \\
\text { Role }\end{array}$ \\
\hline Age & Pearson Correlation & 1 & $.470\left(^{*}\right)$ \\
\hline & Sig. (2-tailed) & & .000 \\
\hline & N & 100 & 100 \\
\hline $\begin{array}{l}\text { I have to play more } \\
\text { than one role }\end{array}$ & Pearson Correlation & $.470(* *)$ & 1 \\
\hline & Sig. (2-tailed) & .000 & \\
\hline & N & 100 & 100 \\
\hline
\end{tabular}

** Correlation is significant at the 0.01 level (2-tailed). 
According to above analysis in the table the Pearson's correlation (.470) is greater than 0.01 level, hence, there is a correlation between Job role and Stress.

\section{Result - H3}

There is a correlation between Job role and Stress is proved.

Table 9: Job Insecurity and Stress

ANOVA

\begin{tabular}{|l|c|c|c|c|c|}
\hline & Sum of Squares & df & Mean Square & F Value & LOS \\
\cline { 1 - 5 } Between Groups & 11.888 & 3 & 3.963 & 2.256 & \multirow{2}{*}{ Significant @ 5\% level } \\
\cline { 1 - 4 } Within Groups & 159.839 & 91 & 1.756 & & \\
\hline Total & $\mathbf{1 7 1 . 7 2 6}$ & $\mathbf{9 4}$ & & & \\
\hline
\end{tabular}

According to the above table, the F value 2.256 is greater than the table value the result is significant at $5 \%$ level hence there is a significant relationship between Job insecurity and stress.

\section{Result - H4}

There is a significant relationship between Job insecurity and stress.

Table 10: Showing Poor Working Environment and Stress ANOVA

\begin{tabular}{|l|c|c|c|c|c|}
\hline \multicolumn{1}{|c|}{ Source } & Sum of Squares & Df & Mean Square & F value & LOS \\
\hline Between Groups & 3.239 & 3 & 1.080 & 586 & Significant @ 5\% level \\
\hline Within Groups & 176.921 & 96 & 1.843 & & \\
\hline Total & $\mathbf{1 8 0 . 1 6 0}$ & $\mathbf{9 9}$ & & & \\
\hline
\end{tabular}

It is clear from the above table that, the calculated $\mathrm{F}$ value is greater the table value and the result are significant at 5\% level. Hence the alternative hypothesis "There exists a significant relationship between poor working environment and stress" holds good. According to the above analysis, there is a significant relationship between Poor working environment and Stress.

\section{Result - H5}

There exists a significant relationship between poor working environment and stress.

\section{FINDINGS OF THE STUDY}

With the application of SPSS, it can be assumed that there is a significant relationship between the given factors. It is observed that about $80 \%$ of the respondents are having a positive opinion about the parameter studied like help and support from colleagues. The general discussions with the respondents who work as temporary faculties revealed the need for improvement in areas such as salary and job security. Respondents are satisfied with the nature of their job as well as superior's behaviour and support towards them. Nearly $40 \%$ of the respondents have neutral or negative feelings, towards recognition of their efforts and they are in expectation of rewards and appreciation for their accomplishment of tasks and challenges at workplace. 


\section{CONCLUSIONS}

The experience of stress at work is to a large extent affected by the level of control they have over their working condition / pressures. The result of the study reveals that $75 \%$ of respondents always have pressure because of environmental factors like poor relationship at workplace, role conflict, job insecurity, poor pay prospectus, strict control, and restrictions. The study also reflects that majority of the respondents have an opinion that their efforts are always not recognized in the Institution. The study concludes that job insecurity and poor pay prospectus, poor relationship at workplace, job conflict, lack of recognition, are the main causes of stress.

\section{REFERENCES}

1. Brewer Michaeland Landers John (2003). "Relationship between Job stress and Job Satisfaction among Industrial and Technical Teacher Educators" Journal of Career and Technical Education, Vol 3 Issue 11

2. Zhang, jianwei.(2010).Organisational climate and its effects on organisational variables: an empirical study. International journal of psychological studies, vol.2, Issue .2,

3. Dhanabhakyam \& Anitha (2011), A Study On Stress Management Of Working Women In Coimbatore District International Journal of Multidisciplinary Research Vol.1 Issue 7

4. Waruba, R., \& Abedin, B.(2015, July). Investigating massive open online courses (MOOCS) opportunities for developing countries: Case of Papua New Guinea. In Pacific Asia Conference on Information Systems. AISEL.

5. Parilla, S. Eric.(2012). Level of stress experienced by NWU Employees: Towards developing A Stress Management. Asian journal of management research. vol.2

6. Vijayadurai \&.Venkatesh (2012), A Study on Stress Management among Women College Teachers in Tamilnadu, India Pacific Business Review International Volume 5 Issue 2

7. Journal of the Indian Academy of Applied Psychology. vol. 33, Issue . 2,

8. International Journal of Research in Medical Sciences Vol 3 Issue 11

9. Journal of Retailing and Consumer services, vol. 7 Issue 4

10. Journal of Research and Development (JMRD) Vol. 1 Issue 1

11. International Journal Of Environmental Sciences Volume 2, Issue 4

12. International Journal of Recent Advances in Organizational Behaviour and Decision Sciences (IJRAOB) An Online International Monthly Journal (ISSN: 2311-3197) 2014 Vol: 1 Issue 1.

13. Organisational Behaviour - Stephen P Robins

$$
\text { Fred Luthans }
$$

Miner

Donald R Sims

14. Lennard Brown S. (2001) Stress and Depression

15. Aldwin, Corolyn M. "Stress coping and development-An Integrative Perspective"

16. Ashwathappa, K. “ Human Resource and Personnel Management 
17. Khanka, S S. "Human Resource Management (Text and Cases)"

18. http://www.cdc.gov/niosh/topics/stress

19. http://www.hazards.org 
